\title{
How Did Ethiopian Christians Come to Know the Parisian Cephalophoric Martyr Bishop Dionysius?
}

\author{
Michael Muthreich
}

$1 \quad$ Introductory Remarks

Everyone dealing with Dionysius the Areopagite has to answer the question about whom exactly he is speaking. There are at least three possible answers. He may speak about the "original" Dionysius, the one who followed Paul after his sermon at the Areopagus and became Christian, even though we do not know much about him because we do not have much pertinent information. Alternatively, he may speak about the author of the Corpus Dionysiacum about whom one can say quite a lot with regard to theology and philosophy. He may speak as well about the Parisian cephalophoric bishop to fill the audience or the reader with wonder and amazement and maybe there are still others he can speak about, when treating Dionysius the Areopagite. I will focus on the three mentioned individuals who became one single "Dionysius" by certain traditions.

The centuries in which the three Dionysii lived are quite easily to indicate: It is the first century for the "original" Dionysius, the third century for the cephalophoric Parisian Bishop Dionysius, who — as an aside — is the very first Christian cephalophore, ${ }^{1}$ and the late fifth or early sixth century for the "Corpus Dionysius." The identification of the "Corpus Dionysius" with the "original" Dionysius took place soon after or maybe already with the appearance of the Corpus Dionysiacum collected and commented by John of Scythopolis in the sixth century. The Parisian bishop "joined the party" in the ninth century "with a little help" of Hilduin, abbot of the abbey of Saint Denis located close to the city of Paris. It was there that the merging of these three different persons took place. $^{2}$

1 "[N]ovo et prius inaudito miraculo." Michael Lapidge, Hilduin of Saint-Denis: The Passio S. Dionysii in Prose and Verse (Leiden: Brill, 2017), 696.

2 Lapidge however states that Hilduin on his part drew on a certain anonymus "Passio S. Dionysii" in which the Parisian Dionysius was first identified with the Areopagite. In addition, the account of the miraculous cephalophory is told there for the first time. See ibid. 66o. 
Anyway, in oriental Christianity as a whole - and thus also in Ethiopia - the identification of Dionysius, the disciple of Paul, with the author of the Corpus Dionysiacum was accepted undisputedly, while Oriental churches generally speaking were ignorant of the existence of the Parisian bishop or Dionysius' decapitation in the Far West! Were they really ignorant of him? No, not all of them: The Ethiopian Orthodox Täwahədo Church for example did in fact know him or, to be more precise, did know about his decapitation in the West, including the miracle of him carrying his head after having had it cut off, no later than

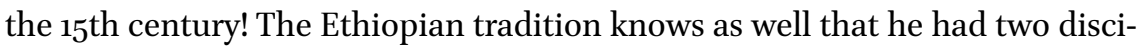
ples who were beheaded with him. In the West, their names are Eleutherius and Rusticus, while they became Äryanos and Wusefos in the Ethiopian tradition. So, in which text can we find this story about Dionysius the cephalophore in the Ethiopic tradition? It is the so-called autobiography of Dionysius the Areopagite, the Narratio de vita sua (Clavis Patrum Graecorum 6633), ${ }^{3}$ also extant in Syriac, ${ }^{4}$ Armenian, ${ }^{5}$ Arabic, ${ }^{6}$ Coptic ${ }^{7}$ and Georgian ${ }^{8}$ but not in Greek or Latin. This text, usually read on Good Friday in the Coptic and the Ethiopic tradition of the Orthodox Täwahədo Church, claims to be a narration of Dionysius in which he reports a vision he had in Heliopolis during an earthquake and a solar eclipse. It turns out that these, as they were non-natural phenomena, occurred because of the crucifixion of Christ. Dionysius' vision anticipates the correlation that he eventually understood after Saint Paul had come to Athens and held his sermon at the Areopagus. This correspondence of his vision with the report of Saint Paul was decisive for him to become a Christian.

3 Mauritius Geerard, ed., Clavis Patrum Graecorum. Vol. 3, A Cyrillo Alexandrino ad Iohannem Damascenum, 2nd ed. (Turnhout: Brepols, 2003), 276. For further information about the text tradition, see: André Binggeli, "Les traditions hagiographiques orientales liées à Denys l'Aréopagite." Bibliothèque de l'école des chartes 172 (2018): 141-153.

4 Marc-Antoine Kugener, "Une autobiographie syriaque des Denys l'Aréopagite," Oriens Christianus 7 , no. 1 (1907): 292-348.

5 Nerses Akinian, "Geschichte des heiligen Dionysius Areopagita," in Materialien zum Studium des armenischen Martyrologiums, ed. Nerses Akinian (Vienna: Mechitaristen Buchdruckerei, 1914), 35-42.

6 Paul Peeters, "قصة القديس ديونيسيوس الاريوياغي (The Story of St. Dionysius the Areopagite)," al-Mašriq 12 (1909): 118-127.

7 Oskar von Lemm, "Eine dem Dionysius Areopagita zugeschriebene Schrift in koptischer Sprache," Bulletin d'Académie Impériale des Sciences de St.Pétersbourg 12, no. 3 (1900): 267306.

8 Paul Peeters, "La version ibéro-arménienne de l' autobiographie de Denys l' Aréopagite," Analecta Bollandiana 39 (1921): 277-313. 
The identification of Dionysius the Areopagite with the Parisian martyr bishop indicates a postscript, the narration being essentially complete and some additional information on Dionysius given. The Ethiopic text reads:

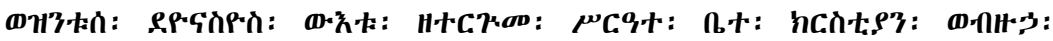

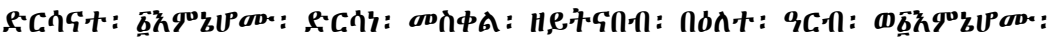

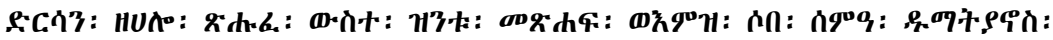

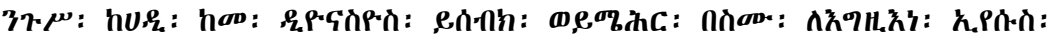

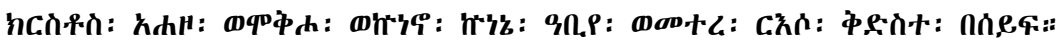

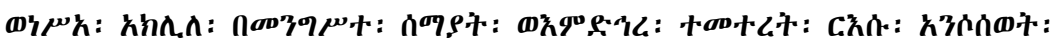

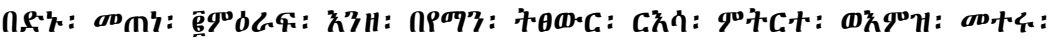

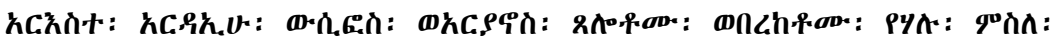

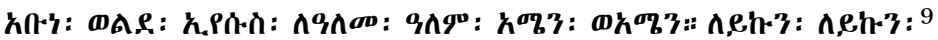

And this is indeed Dionysius who expounded the ecclesiastical hierarchy and many homilies. One of those is the homily about the (Holy) Cross, to be read on Good Friday. Another one of them is the homily that is written down in this book. Afterwards, when the infidel king Domitianus heard that Dionysius preached and taught in the name of our Lord Jesus Christ, he arrested and imprisoned him, and punished him severely. And he cut off his holy head with the sword. And he received the crown (of martyrdom) in the Kingdom of Heaven. And after his head had been cut off his (dead) body still ran two miles carrying the cut-off head on the right. And afterwards they cut off the heads of his disciples Wusefos and Äryanos. May their intercession and their blessing be with our father Wäldä Iyäsus in all eternity! Amen and Amen. So be it. So be it.

This short postscript tells the martyrdom of Dionysius but says nothing about where it happened. However, the fact that he went to the Far West is told in another manuscript, namely in EMML $3802 .{ }^{10}$ There we read:

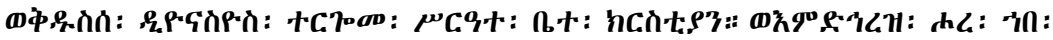

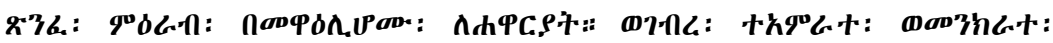
-nH?:3+: Dionysius Areopagita," Oriens Christianus 102 (2019): 6 o. 
And the holy Dionysius expounded the ecclesiastical hierarchy. And afterwards he went to the Far West, in the days of the apostles, and performed a lot of miracles and wonders.

\section{Biography and Autobiography}

Incidentally looking at manuscript EMML 3802 we come across another peculiarity of the text at hand in the Ethiopic tradition, namely that the same text essentially exists in two different versions, once in the form of an autobiography (Dionysius speaks about himself, the proper Narratio de vita sua), but also in the form of a biography (Dionysius is spoken about). Although the narrative form is different, the contents are similar.11 They are, of course, easy to distinguish by their incipit and the corpora of texts, which they are part of usually.

To speak about the different text traditions the incipit of both texts are first of interest:

a) The incipit of the autobiography ${ }^{12}$

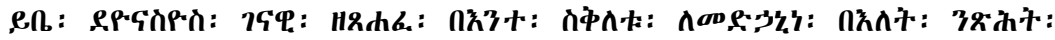

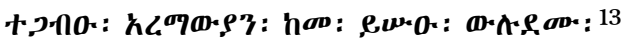

Dionysius the heathen priest [who wrote] about the crucifixion of our Saviour said: At the time of purification [literally: on the pure day] the heathens gathered to sacrifice their sons.

b) The incipit of the biography

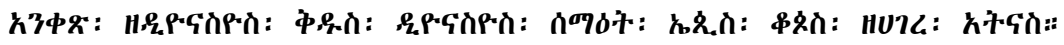

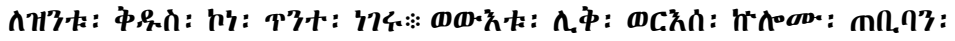

Section on Saint Dionysius the martyr bishop of Athens: This is the beginning of the report about this saint. He was master and head of all the wise men.

11 The biography omits the first part of the Narratio de vita sua though, which tells about the education of Dionysius and starts with him being the head of the philosophers.

12 The Christian basmala precedes the given incipit.

13 Cf. Muthreich, "Die äthiopische 'narratio de vita sua'," 52. 
There are, in fact, different beginnings for the biography. The one given above is from manuscript Orient 767 (CCLXIII) ${ }^{14}$ of the British Library. Another quite common incipit is:

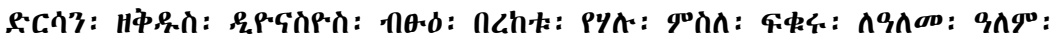

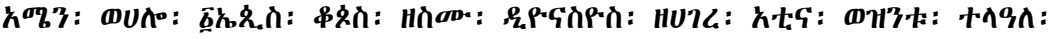

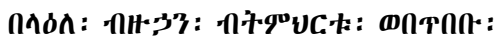

Homily on the holy and blessed Dionysius, may his blessings be with his beloved forever. Amen. There was a bishop called Dionysius in the city of Athens. He was superior to most as far as erudition and wisdom are concerned.

In the Ethiopian Synaxarium as given by Colin ${ }^{15}$ there is a lengthy incipit of the biography, which differs again because it is imbedded in a larger context (the lecture of the sixth of Təqəmt). It is not a stand-alone text here.

The different versions of the Narratio de vita sua are part of the following corpora of texts:

a) The autobiography:

- Corpora containing saints' lives including the Gädlä Täklä Haymanot.

- Lectionary for Passion Week.

b) The biography:

- The Book of the Commemoration of the Saviour of the World (ang do.:

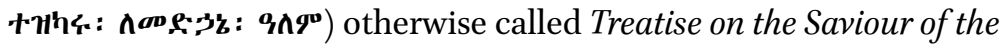

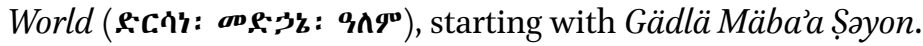

- Lectionary for Passion Week.

- Synaxaria.

Both texts are also quite often part of the Lectionary for Passion Week or Good

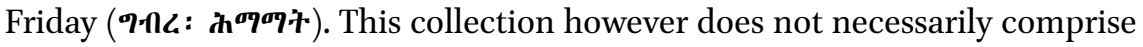
either the autobiography or the biography.

Another difference between the two versions-already obvious from the corpora of texts, which they are part of-is the date in the liturgical calendar when they are to be read out. The autobiography we only find in the liturgy for Good Friday after the prayer of the sixth hour, which is the usual date for reading it in the Coptic-Arabic tradition, as has been mentioned above. The biography on the other hand is to be read out on this same day (Lectionary for

\footnotetext{
14 For a short description of the manuscript, see the list below: b) The Biography, no. 5.

15 Gérard Colin, "Le synaxaire éthiopien. Mois de Tequemt," in Patrologia orientalis 44, fasc. 1 (Turnhout: Brepols, 1987), 26-27.
} 


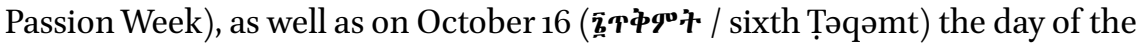
martyrdom of Dionysius the Areopagite as given in the Synaxarium.

\section{4}

\section{Manuscripts}

Regarding the age of the manuscripts containing the autobiography, they are quite young, which is not uncommon for Ethiopic manuscripts in general. They usually range from between the 18th and the 2oth century. As far as the biography is concerned there are Synaxaria including the biography dating back to the 16 th and even $15^{\text {th }}$ centuries.

As an aside: There exists a manuscript of the Narratio de vita sua possibly dating back to the thirteenth century. The Narratio de vita sua there is part of a homily of Benjamin of Alexandria for Passion Week. ${ }^{16}$ This version is without the mentioned postscript though.

In the following, I present a selective list of relevant manuscripts:

a) The autobiography:

1. Addis Abäba, Church of St. Peter and Paul, Kolfe, Cod. EMmL 242

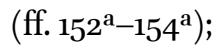

Parchment; anno 1924; Lectionary for Passion Week. ${ }^{17}$

2. Addis Abäba, Lədäta Maryam Church, Cod. EMML 411 (ff. $15^{6^{a}-157^{\mathrm{a}}}$ ); Parchment; early 2oth cent.; Lectionary for Passion Week. ${ }^{18}$

3. Goğǧam, Märțulä Maryam Monastery, Cod. EMDA oooo8 (IMG 181 jpg; 182 jpg);

Parchment; 2oth cent.; Lectionary for Passion Week. ${ }^{19}$

4. Goğğam, Qäraneyo Mädhane 'Aläm Monastery, Cod. EMDA 00183 (IMG 240 jpg, 241 jpg);

16 I owe this knowledge to the kind notification of Ted Erho. He informed me that there are no less than five manuscripts of this homily, all except one in a fragmentary state. Unfortunately, he did not provide any further details.

17 William F. Macomber, A Catalogue of Ethiopian Manuscripts Microfilmed for the Ethiopian Manuscript Microfilm Library (Addis Abäba) and for the Hill Monastic Manuscript Library (Collegeville). Vol. 1 (Collegeville, Minnesota: Hill Monastic Manuscript Library and St. John's Abbey and University, 1975), 253.

18 William F. Macomber, A Catalogue of Ethiopian Manuscripts Microfilmed for the Ethiopian Manuscript Microfilm Library (Addis Abäba) and for the Hill Monastic Manuscript Library (Collegeville). Vol. 2 (Collegeville, Minnesota: Hill Monastic Manuscript Library and St. John's Abbey and University, 1976), 128.

19 For a detailed description of the manuscript, see the website of the "Virtual Hill Museum \& Manuscript Library": https://w3id.org/vhmml/readingRoom/view/138171. 
Parchment; 19th cent. (?); Lectionary for Passion Week. ${ }^{20}$

5. Š̈̈wa, Church of Mitaq Ämanu'el, Ankobarr, Cod. EMmL 2338 (ff. $\left.194^{\mathrm{b}}-196^{\mathrm{a}}\right)$;

Parchment; 1813-1847; Lectionary for Passion Week. ${ }^{21}$

6. Šäwa, Church of Hulara Madhane 'Aläm, Assagərt, Cod. E M M L 3629 (ff. $\left.2^{\mathrm{a}}-4^{\mathrm{b}}\right)$;

Parchment; 18th cent.; Gädlä Täklä Haymanot. ${ }^{22}$

7. Wällo, Church of Wäldəya Mika’el, Cod. Eмm L 3803 (ff. $137^{\mathrm{a}}-13^{\mathrm{b}}$ ); Parchment; 19th/2oth cent.; Lectionary for Passion Week. ${ }^{23}$

8. Wällo, Church of Boru Śəllase, Cod. EMML 4775 (ff. $\left.42^{\mathrm{b}}-45^{\mathrm{b}}\right) ;{ }^{24}$ Parchment; 19th/2oth cent.; Lectionary for Passion Week. ${ }^{25}$

9. Wällo, Church of Gännätä Giyorgis, Cod. EMML 4856 (ff. $142^{\mathrm{b}}-144^{\mathrm{a}}$ ); Parchment; 2oth cent.; Lectionary for Passion Week. ${ }^{26}$

1 o. Wällo, Church of Mänbärä Dähäy Täklä Haymanot, Cod. E M M L 4967 (ff. $142^{\mathrm{b}}-144^{\mathrm{a}}$ );

Parchment; anno 1924; Lectionary for Passion Week. ${ }^{27}$

b) The biography:

1. Addis Abäba, Church of the Saviour of the World, Gulale, E MM L 519 (ff. $79^{\mathrm{b}}-83^{\mathrm{a}}$ );

Parchment; 2oth cent.; Treatise on the Saviour of the World. ${ }^{28}$

2. Addis Abäba, Lədäta Maryam Church, EMML 537 (ff. $119^{\mathrm{a}}-121^{\mathrm{a}}$ );

Parchment; anno 1932; Treatise on the Saviour of the World. ${ }^{29}$

20 For a detailed description of the manuscript, see the website of the "Virtual Hill Museum \& Manuscript Library": https://w3id.org/vhmml/readingRoom/view/500221.

21 Getatchew Haile, A Catalogue of Ethiopian Manuscripts Microfilmed for the Ethiopian Manuscript Microfilm Library (Addis Abäba) and for the Hill Monastic Manuscript Library (Collegeville). Vol. 6 (Collegeville, Minnesota: Hill Monastic Manuscript Library and St. John's University, 1982), 405.

Getatchew Haile, A Catalogue of Ethiopian Manuscripts Microfilmed for the Ethiopian Manuscript Microfilm Library (Addis Abäba) and for the Hill Monastic Manuscript Library (Collegeville). Vol. 9 (Collegeville, Minnesota: Hill Monastic Manuscript Library and St. John's University, 1987), 77-78.

23 Ibid. 159-16o.

24 This manuscript is in a very fragmentary condition.

25 Getatchew Haile, A Catalogue of Ethiopian Manuscripts Microfilmed for the Ethiopian Manuscript Microfilm Library (Addis Abäba) and for the Hill Monastic Manuscript Library (Collegeville). Vol. 10 (Collegeville, Minnesota: Hill Monastic Manuscript Library and St. John's University, 1993), 3 O7.

26 Ibid. 337-338.

27 Ibid. 373.

28 Macober, Catalogue. Vol. 2, 257.

29 Ibid. 272. 
3. Addis Abäba, Church of the Saviour of the World, EmmL 766 (ff. $59^{\text {b_ }}$ $\left.62^{\mathrm{a}}\right)$;

Parchment; end of 19th cent.; Treatise on the Saviour of the World.$^{30}$

4. Addis Abäba, Institute of Ethiopian Studies, EM ML 1553 ( $\left(\mathrm{ff}^{7} \mathbf{2}^{\mathrm{b}}-75^{\mathrm{b}}\right.$ ); Photocopy of an unidentified 2oth century manuscript; The Book of the Commemoration of the Saviour of the World. ${ }^{31}$

5. London, British Library, Orient 767 [CCLXIII] (ff. $\left.178^{\mathrm{b}}-179^{\mathrm{b}}\right)$;

Parchment; 18th cent; Collection of saints' lives from the Lectionary for Passion Week (?).32

6. Šäwa, Church of Säll Dəngay Marqos, EMML 4440 (ff. 141 $\left.1^{\mathrm{a}}-141^{\mathrm{b}}\right)$;

Parchment; anno 1884/5; Lectionary for Passion Week. ${ }^{33}$

7. Wällo, Church of Wäldəya Mika'el, Cod. EMML $3802\left(\mathrm{ff}^{1} 16^{\mathrm{b}}-197^{\mathrm{a}}\right)$;

Parchment; 19th/2oth cent.; Lectionary for Passion Week. ${ }^{34}$

8. Wällo, Church of Gännätä Giyorgis, EMML 4856 (ff. $142^{\mathrm{b}}-144^{\mathrm{a}}$ );

Parchment (?); 2oth cent.; Lectionary for Passion Week. ${ }^{35}$

9. Wällo, Church of Däbrä Betel Śəllase, EM ML 4898 (ff. $18 \mathrm{O}^{\mathrm{a}}-18 \mathrm{o}^{\mathrm{b}}$ );

Parchment (?); 2oth cent.; Lectionary for Passion Week. ${ }^{36}$

10. Wällo, Church of Mänbärä Däḥay Täklä Haymanot, EMML 4967 (ff. $122^{\mathrm{a}}-123^{\mathrm{b}}$ );

Parchment (?); 2oth cent.; Lectionary for Passion Week. ${ }^{37}$

Additionally, Colin in his edition of the Ethiopian Synaxarium lists the following manuscripts: ${ }^{38}$

1. Paris, Bibliothèque nationale de France, Éthiopien $126(1699) \cdot{ }^{39}$

30 William F. Macomber, A Catalogue of Ethiopian Manuscripts Microfilmed for the Ethiopian Manuscript Microfilm Library (Addis Abäba) and for the Hill Monastic Manuscript Library (Collegeville). Vol. 3 (Collegeville, Minnesota: Hill Monastic Manuscript Library and St. John's Abbey and University, 1978), 77-78.

William F. Macomber and Getatchew Haile, A Catalogue of Ethiopian Manuscripts Microfilmed for the Ethiopian Manuscript Microfilm Library (Addis Abäba) and for the HillMonastic Manuscript Library (Collegeville). Vol. 5 (Collegeville, Minnesota: Hill Monastic Manuscript Library and St. John's Abbey and University, 1981), 51.

William Wright, Catalogue of the Ethiopic Manuscripts in the British Museum (London: Longmans \& $\mathrm{Co}, 1877), 173$.

33 Getatchew Haile, Catalogue. Vol. 10, 155-156.

34 Getatchew Haile, Catalogue. Vol. 9, 158.

35 Ibid. 337-338.

36 Ibid. $35^{-}-35^{2}$.

$37 \quad$ Ibid. 273 .

38 Colin, Le synaxaire éthiopien, 5 . I only give the manuscripts mentioned by Colin. To provide a complete listing of synaxaria would go far beyond the scope of this article.

For a detailed description of the manuscript see the website of the "Bibliothèque nationale 
2. Paris, Bibliothèque nationale de France, Éthiopien 677 (15th century). ${ }^{40}$

3. Paris, Bibliothèque nationale de France, Éthiopien d'Abbadie 66 (15th-16th century). ${ }^{41}$

4. Wällo, Hayq Hsțifanos Monastery, EMML 2054 (1581). ${ }^{42}$

5. Ethiopia (?), EMML $695^{2}$ (15th century, mutilated). ${ }^{43}$

5. Ethiopia (?), EMML 6458 (15th century). ${ }^{44}$

Origin of the Information about the Parisian Martyr Bishop in Ethiopia

It is easy to detect where the information about Dionysius travelling to the Far West, as well as about the decapitation of him and his two disciples comes from. It stems from the biography of Dionysius written by the already mentioned Hilduin abbot of Saint Denis around the years $835^{-840.45}$ Comparing the biography of Hilduin with the Narratio de vita sua, we do not find many correspondences except for some main features that are explicable by premises given in the Scriptures and the Corpus Dionysiacum. The biography composed by Hilduin differs from the Narratio de vita sua for example in giving the reason of Dionysius' conversion to Christianity, at least as far as the impetus for his accepting baptism is concerned. The Narratio de vita sua narrates that the correspondence of what Dionysius saw in his vision in Heliopolis with what Saint Paul told at the Areopagus about the crucifixion of Christ was his motive for

de France": https://archivesetmanuscrits.bnf.fr/ark:/12148/cc1056oob (systematically used in Colin's edition).

40 For a detailed description of the manuscript see the website of the "Bibliothèque nationale de France": https://archivesetmanuscrits.bnf.fr/ark:/12148/cc1030542.

41 For a detailed description of the manuscript see the website of the "Bibliothèque nationale de France": https://archivesetmanuscrits.bnf.fr/ark:/12148/cc109o411 (systematically used in Colin's edition).

42 For a detailed description of the manuscript, see the website of the "Virtual Hill Museum \& Manuscript Library": https://w3id.org/vhmml/readingRoom/view/203883 (systematically used in Colin's edition).

43 For a detailed description of the manuscript see the website of the "Virtual Hill Museum \& Manuscript Library": https://w3id.org/vhmml/readingRoom/view/200577.

44 I was not able to get further information about this manuscript. It was systematically used in Colin's edition. At the "Virtual Hill Museum \& Manuscript Library," there are no images and no cataloging metadata available yet as David Calabro informed me on 19 March 2021, to whom I would like to express my thanks. 
receiving baptism. In Hilduin's narration, the rationale for this fact is the story of a certain blind man whom Saint Paul cured. Dionysius eventually desired baptism after becoming aware of this miraculous cure.

The Arabic tradition of the Narratio de vita sua knows the story of Dionysius going to the west, to Paris, his decapitation together with two of his disciples and him carrying his head after decapitation as well. This fact testifies at least one manuscript from Beirut (Université Saint-Joseph, Bibliothèque orientale no. 616$){ }^{46}$ Here we find - in a second part as Peeters says-a lengthy narration of what tells Hilduin's biography of Dionysius' martyrdom at the end of the Narratio de vita sua. It is very likely that Ethiopians learned the story of Dionysius' decapitation in the west by way of this Arabic narration or a similar one. The narration of Dionysius' and his disciples' martyrdom anyway is much shorter in the Gə'əz version than in the one given by the mentioned Arabic manuscript. Whether there are Arabic manuscripts containing the abridged martyrdom of Dionysius and his disciples Rusticus and Eleutherius as told in the Gəəəz Narratio de vita sua, and upon what Vorlage such Arabic translations depend, remains yet a task of further research.$^{47}$ Anyway, it suggests itself very much to explain the names Wusefos and Äryanos as wrong spellings derived from misunderstanding the Arabic writing for Rusticus and Eleutherius. ${ }^{48}$

\section{Transmission of the Ethiopian Narratio de vita sua}

To understand the tradition of the Narratio de vita sua in Ethiopic we have to take a quick look at Gə`əz literature. In doing so, I generally follow Getatchew Haile's Encyclopaedia Aethiopica article on this subject. ${ }^{49}$ Peeters assumes the Narratio de vita sua to have been written in Greek originally, but like the Epis-

46 Cf. Peeters, Story of St. Dionysius, 127. The manuscript is online at the "Virtual Hill Museum \& Manuscript Library” website (https://w3id.org/vhmml/readingRoom/view/5050o6). For the Narratio de vita sua see page 208 (...6c105.jpg)—239 (..6c12o.jpg). Peeters presents the text until a few lines before the end of page 235 (...6c113.jpg). He made a sign (cross) in the relevant place. It was surely him as well who wrote down the numbers of the folia for the text he edited with a pencil. For Dionysius' martyrdom see page 236-237 (...6c119.jpg).

47 A detailed examination about this topic will provide Corpus Dionysiacum III, 2, which is currently in preparation at the Academy of Sciences and Humanities, Patristische Kommission in Göttingen.

48 Colin, by the way, interprets Wusefos (he writes 'Usefos) as Joseph and Äryanos (he writes 'Uryanos) as Urien. Cf. Colin, Le synaxaire éthiopien, 29 and 31. He does not consider Hilduins account in conjunction with a (misleading) translation from Arabic to explain the names.

49 Cf. Getatchew Haile, “Gə`əz literature," in EAe 2 (2005): 736-741. 
tula ad Timotheum de passione apostolorum Petri et Pauli ascribed to Dionysius the Areopagite (Clavis Patrum Graecorum 6631) ${ }^{50}$ it is not preserved in a Greek manuscript. Kugener on the other hand thinks of a Syriac original whereas Binggeli says "la question de la langue originale de l'Autobiographie, syriaque ou grec perdu, reste entire."51 Anyway, the Ethiopic Narratio de vita sua is certainly a translation from Arabic. ${ }^{2}$

The Arabic period of Gə`əz literature starts already in the time of the Zagwe dynasty (1oth-13th century). There is only the above-mentioned uncertain witness of a translation at that early date (13th century) though. In the 14th century Abba Sälama, patriarch of the Ethiopian Church (1348-1388), initiated the translation of the Lectionary for Passion Week of the Coptic Church from Arabic into Gə'əz. In this lectionary, the Narratio de vita sua is read after the prayer of the sixth hour on Good Friday as has been pointed out above. Early manuscripts of it however do not display the text of either the autobiography or the biography. ${ }^{53}$ It looks like the Narratio de vita sua did not belong to the original text collection but was added later.

The Ethiopian manuscripts containing the Narratio de vita sua proper are usually quite young as has been shown. The biography on the other hand is older. We find it in manuscripts of synaxaria going back to the 15th century. This leads to a closer look at the Ethiopian Synaxarium, ${ }^{54}$ which is a translation depending on the Synaxarium of the Coptic Church and dating from the end of the 14th century. The reading for the sixth of the month of Bābah though, which corresponds to the sixth of Təqəmt, actually does not display the Narratio de vita sua. ${ }^{55}$

The Narratio de vita sua finally is also part of the mentioned homily of Benjamin of Alexandria for Passion Week. The Ethiopian manuscript containing the homily possibly goes back to the thirteenth century as Ted Erho thank-

$50 \quad$ Geerard, Clavis Patrum Graecorum, 275 .

51 Cf. Binggeli, Les traditions hagiographiques, 146-147.

52 This is proven by the use of an Arabic word (al-maknün — meaning "the Hidden" - for "the unknown God," cf. Act. 17, 23) for example.

53 See for example: Wright, Catalogue 1877, 136-140 or Pisani, Vitagrazia. "Abbā Salāmā and his Role of Commissioner of the Gabra Hamāmät: an Additional Evidence from Two Witnesses from Təgray, Northern Ethiopia," Comparative Oriental Manuscript Studies Bulletin 5, no. 2 (2019): 129-15o.

54 Here I refer to Gérard Colin and Alessandro Bausi, "Sənkəssar," in EAe 4 (2010): 621-623.

55 Cf. René Basset, "Le synaxaire arabe Jacobite (rédaction copte)," in Patrologia orientalis 1, fasc. 3 (Paris: Firmin-Didot, 1907), 319-320. Basset says, he uses two manuscripts for his edition: Paris, Bibliothèque nationale de Paris, Arabe 256 (16th century) and Paris, Bibliothèque nationale de Paris, Arabe $4869-4870$ (14th century). Since the publication is quite old, further research is necessary. 
fully let me know. Surely, this date is just an educated guess. Still it may well be that the Narratio de vita sua was actually copied even before the $15^{\text {th cen- }}$ tury manuscripts of synaxaria containing the biography. The earliest translation of the Narratio de vita sua into Gə'əz could indeed go back to the 14th or perhaps even to the late 13th century. Anyway, there are no hints for an acquaintance with the martyrdom of Dionysius in the west at such an early date.

\section{List of References}

Akinian, Nerses. "Geschichte des heiligen Dionysius Areopagita." In Materialien zum Studium des armenischen Martyrologiums, edited by Nerses Akinian, 35-42. Vienna: Mechitaristen Buchdruckerei, 1914.

Basset, René. “Le synaxaire arabe Jacobite (rédaction copte).” In Patrologia orientalis 1, fasc. 3. Paris: Firmin-Didot, 1907.

Binggeli, André. “Les traditions hagiographiques orientales liées à Denys l'Aréopagite.” Bibliothèque de l'école des chartes 172 (2018): 141-153.

Colin, Gérard. "Le synaxaire éthiopien. Mois de Tequemt." In Patrologia orientalis 44, fasc. 1. Turnhout: Brepols, 1987.

Colin, Gérard, and Bausi, Alessandro. “Sənkəssar." In EAe 4 (2010): 621-623.

Geerard, Mauritius, ed. Clavis Patrum Graecorum. Vol. 3, A Cyrillo Alexandrino adIohannem Damascenum. 2nd ed. Turnhout: Brepols, 2003.

Getatchew Haile. A Catalogue of Ethiopian Manuscripts Microfilmed for the Ethiopian Manuscript Microfilm Library (Addis Abäba) and for the Hill Monastic Manuscript Library (Collegeville). Vol. 6. Collegeville, Minnesota: Hill Monastic Manuscript Library and St. John's University, 1982.

Getatchew Haile. A Catalogue of Ethiopian Manuscripts Microfilmed for the Ethiopian Manuscript Microfilm Library (Addis Abäba) and for the Hill Monastic Manuscript Library (Collegeville). Vol. 9. Collegeville, Minnesota: Hill Monastic Manuscript Library and St. John's University, 1987.

Getatchew Haile. A Catalogue of Ethiopian Manuscripts Microfilmed for the Ethiopian Manuscript Microfilm Library (Addis Abäba) and for the Hill Monastic Manuscript Library (Collegeville). Vol. 10. Collegeville, Minnesota: Hill Monastic Manuscript Library and St. John's University, 1993.

Getatchew Haile. “Gə`əz literature.” In EAe 2 (2005): 736-741.

Kugener, Marc-Antoine. "Une autobiographie syriaque des Denys l'Aréopagite." Oriens Christianus 7, no.1 (1907): 292-348.

Lapidge, Michael. Hilduin of Saint-Denis: The Passio S. Dionysii in Prose and Verse. Leiden: Brill, 2017 . 
Lemm, Oskar von. "Eine dem Dionysius Areopagita zugeschriebene Schrift in koptischer Sprache." Bulletin d'Académie Impériale des Sciences de St.-Pétersbourg 12, no. 3 (1900), 267-306.

Macomber, William F. A Catalogue of Ethiopian Manuscripts Microfilmed for the Ethiopian Manuscript Microfilm Library (Addis Abäba) and for the Hill Monastic Manuscript Library (Collegeville). Vol. 1. Collegeville, Minnesota: Hill Monastic Manuscript Library and St. John's Abbey and University, 1975.

Macomber, William F. A Catalogue of Ethiopian Manuscripts Microfilmed for the Ethiopian Manuscript Microfilm Library (Addis Abäba) and for the Hill Monastic Manuscript Library (Collegeville). Vol. 2. Collegeville, Minnesota: Hill Monastic Manuscript Library and St. John's Abbey and University, 1976.

Macomber, William F. A Catalogue of Ethiopian Manuscripts Microfilmed for the Ethiopian Manuscript Microfilm Library (Addis Abäba) and for the Hill Monastic Manuscript Library (Collegeville). Vol. 3. Collegeville, Minnesota: Hill Monastic Manuscript Library and St. John's Abbey and University, 1978.

Macomber, William F. and Getatchew Haile. A Catalogue of Ethiopian Manuscripts Microfilmed for the Ethiopian Manuscript Microfilm Library (Addis Abäba) and for the Hill Monastic Manuscript Library (Collegeville). Vol. 5. Collegeville, Minnesota: Hill Monastic Manuscript Library and St. John's Abbey and University, 1981.

Muthreich, Michael. "Die äthiopische 'narratio de vita sua' (CPG 6633) des Dionysius Areopagita." Oriens Christianus 102 (2019): 49-62.

Peeters, Paul. "قصة القديس ديونيسيوس الاريوياغي (The Story of St. Dionysius the Areopagite)." Al-Machriq 12 (1909): 118-127.

Peeters, Paul. "La version ibéro-arménienne de l' autobiographie de Denys l' Aréopagite." Analecta Bollandiana 39 (1921): 277-313.

Pisani, Vitagrazia. "Abbā Salāmā and his Role of Commissioner of the Gəbra Həmāmāt: an Additional Evidence from Two Witnesses from Təgray, Northern Ethiopia." Comparative Oriental Manuscript Studies Bulletin 5, no. 2 (2019): 129-150.

Wright, William. Catalogue of the Ethiopic Manuscripts in the British Museum. London: Longmans \& Co, 1877 . 